\title{
Copper isotope for potential thyroid cancer diagnosis
}

\author{
LATIFA SARRA KAZI TANI ${ }^{1,2}$, ALEXANDRA T. \\ GOURLAN $^{3}$, NOURIA DENNOUNI-MEDJATI ${ }^{2}$, MAJDA \\ DALI SAHI $^{2}$, YAHIA HAREK ${ }^{2}$, MOUSSA BELHADJ ${ }^{2}$, \\ PHILIPPE TELOUK ${ }^{4}$ AND LAURENT CHARLET ${ }^{1}$ \\ ${ }^{1}$ ISTerre, CNRS \\ ${ }^{2}$ Université Abou Bekr Belkaid \\ ${ }^{3}$ Université Grenoble Alpes \\ ${ }^{4}$ Ecole Normal Supérieur de Lyon \\ Presenting Author: sarratanikazi@gmail.com
}

Thyroid cancer is the most common endocrine cancer, affecting more women than men. There is no systematic detection of thyroid cancer and it is often accidentally diagnosed during the evaluation of other diseases. The search of diagnostic biomarkers is necessary for the early detection of thyroid cancer. Copper $(\mathrm{Cu})$ is an essential micronutrient for thyroid gland functioning by stimulating the production of thyroxin hormone (T4). Cu can act both as antioxidant and pro-oxidant. Changes in $\mathrm{Cu}$ metabolism have been observed concomitantly with the development of cancer. $\mathrm{Cu}$ naturally has two stable isotopes: ${ }^{63} \mathrm{Cu}$ and ${ }^{65} \mathrm{Cu}$. The development of new sensitive techniques such as multi collector inductively coupled plasma-mass spectrometry (MC-ICP-MS) made possible $\mathrm{Cu}$ isotope variations assessment. Several studies conducted on patients with breast, colorectal and ovarian cancer have shown for serum a significant decrease of ${ }^{65} \mathrm{Cu} /{ }^{63} \mathrm{Cu}$ ratio $\left(\delta^{65} \mathrm{Cu}\right)$ compared to healthy controls and in a mirror image result, a higher value of this ratio in tumor tissue relative to healthy tissue. These results support the hypothesis that Copper isotopes have a strong potential to be markers of cancer [1,2]. In this study, we test the isotopic variation in thyroid cancer, we measured the $\delta^{65} \mathrm{Cu}$ ratio in 45 thyroid cancer patients, 10 thyroid tumor biopsies and 20 healthy controls. The results show very significant differences in serum between cases and controls in the isotopic composition of $\mathrm{Cu}(\mathrm{p}$ $<0.001)$. The serum of the patients was enriched in ${ }^{63} \mathrm{Cu}$, conversely the thyroid biopsies were enriched in ${ }^{65} \mathrm{Cu}$. These changes can be explained by angiogenesis, cell proliferation and cell mass formation. These observations support that $\delta^{65} \mathrm{Cu}$ can be used in the early detection of thyroid cancer.

[1] P. Télouk et al., « Copper isotope effect in serum of cancer patients. A pilot study », Metallomics, vol. 7, n 2, p. 299-308, 2015, doi: 10.1039/C4MT00269E.

[2] B. Toubhans et al., « $\mathrm{Cu}$ isotope ratios are meaningful in ovarian cancer diagnosis », J. Trace Elem. Med. Biol., vol. 62, p. 126611, déc. 2020, doi: 10.1016/j.jtemb.2020.126611. 